\title{
Reason for 1991 Delayed Pecan Shuck Opening Remains Elusive
}

\author{
Ray E. Worley ${ }^{1}$ and Ben Mullinix ${ }^{2}$ \\ University of Georgia, Coastal Plain Experiment Station, Tifton, \\ GA 31793-0748
}

Additional index words. Carya illinoinensis

In 1991, many reports of a delayed shuckopening malady on 'Stuart' pecans [Carya illinoinensis (Wangenh.) K. Koch] in the Albany, Ga., area were received regarding apparently well-managed orchards. This is not the late-season shuck necrosis malady attributed to stress (Sparks et al., 1995) and fungi (Reilly, 1994). Drought stress causes shucks to become flaccid and to eventually dry tightly stuck to the shell (Worley, 1982). For the malady described, the shuck remained green and turgid and kernels remained extremely moist with a dark brown seedcoat. Normal shucks would have been dehisced, and nuts would be dry and ready for harvest.

A light crop load and low insect and disease pressure in 1990 induced an extremely large crop set in 1991. Abundant rain through the sizing stage made the nuts large, but a drought beginning in mid-August forced many growers to irrigate. Rainfall was $168,193,91$, 13, 20, and $5 \mathrm{~mm}$ for June through November, respectively. The historical norms for these months are $115,144,128,92,55$, and $58 \mathrm{~mm}$, respectively. Mean air temperatures from June through November were 25, 27, 26, 24, 19 , and $12 \mathrm{C}$, respectively, with no hard freezes before harvest; historical means for these months are $26,27,27,25,20$, and $15 \mathrm{C}$, respectively.

The degree of the malady varied among trees in a research orchard at Tifton. We attempted to determine if the extent of the malady could be associated with pruning, fertilizer treatments, or any of the usual measured characteristics. The orchard was drip-irrigated, insects were controlled, and foliage condition was excellent at harvest (6 Nov. 1991).

Nuts were harvested from individual trees. Nuts free of shucks were considered "marketable." The moist nuts with unopened shucks

Received for publication 23 Jan. 1995. Accepted for publication 15 May 1995. The cost of publishing this paper was defrayed in part by the payment of page charges. Under postal regulations, this paper therefore must be hereby marked advertisement solely to indicate this fact.

${ }^{1}$ Professor of Horticulture.

${ }^{2}$ Agricultural Research Statistician. 'Stuart' trees. No single variable accounted for $>8 \%$ of the variation in in-shuck yield, and of-shuck and the in-shuck : out-of-shuck (I : O) ratio, 1991.

yApplied annually. the nine variables in the regression equation were associated with only $42 \%$ of the variation. For the I : O ratio, the yield of the marketable nuts accounted for $49 \%$ and no other variable accounted for $>4 \%$ of the variation. Trees with a high yield of marketable nuts had a lower I : O ratio than those with lower yields. Since leaf N did not enter either equation, the differences in the I : $\mathrm{O}$ ratio found in the $\mathrm{N}$ study (Table 1) were probably associated with the differences in yield.

The nuts had few sprouts, but the moist appearance of the kernels of nuts in the shucks suggests a presprouting condition. A similar shuck-opening problem in 1973 was related to high $\mathrm{N}$ rates (Worley, unpublished). Stress from excessive crop load was obviously not related to the delayed shuck opening. The problem was not serious in 1992 through 1994.

\section{Literature Cited}

Reilly, C.C. 1994. Fungi involved in fungal leaf scorch and the shuck disease complex of pecans. Proc. Southeastern Pecan Growers Assn. 87:129142.

SAS Institute. 1989. SAS/STAT user's guide, version 6, 4th ed., vol. 2. SAS Inst., Cary, N.C.

Sparks, D., W. Reed, I.E. Yates, M.W. Smith, and T.G. Stevenson. 1995. Fruiting stress induces shuck decline and premature germination in pecan. J. Amer. Soc. Hort. Sci. 120:43-53.

Worley, R.E. 1982. Tree yield and nut characteristics of pecan with drip irrigation under humid conditions. J. Amer. Soc. Hort. Sci. 107:30-34.

Worley, R.E. 1987. Effect of pruning old noncrowded pecan trees to three heights. Proc. Southeastern Pecan Growers Assn. 80:123-127.

Worley, R.E. 1989. Can we reduce the area covered by nitrogen application. Proc. Southeastern Pecan Growers Assn. 82:171-174.

Worley, R.E. 1990. Long-term performance of pecan trees when nitrogen application is based on prescribed threshold concentrations in leaf tissue. J. Amer. Soc. Hort. Sci. 115:745-749.

Worley, R.E. 1991. Selective limb pruning intensity influences mature pecan tree and nut characteristics. HortScience 26:126-129.

Worley, R.E. 1994. Long-term performance of pecan trees when potassium is based on prescribed threshold concentrations in leaf tissue. J. Amer. Soc. Hort. Sci. 119:434-438.

Table 1. Effect of $\mathrm{N}$ application, based on leaf analysis, on pecans shaken from the tree in-shuck and out-

\begin{tabular}{|c|c|c|c|c|}
\hline \multirow[b]{2}{*}{$\begin{array}{l}\mathrm{N} \text { applied } \\
\left(\mathrm{kg} \cdot \mathrm{ha}^{-1}\right)\end{array}$} & \multirow{2}{*}{$\begin{array}{c}\text { Leaf } \mathrm{N} \\
\text { limit } \\
(\%)\end{array}$} & \multicolumn{2}{|c|}{ Yield } & \multirow[b]{2}{*}{$\begin{array}{l}\mathrm{I}: \mathrm{O} \\
\text { ratio }\end{array}$} \\
\hline & & $\begin{array}{c}\text { Out-of-shuck } \\
\left(\mathrm{kg} / \text { tree }^{\mathrm{z}}\right)\end{array}$ & $\begin{array}{r}\text { In-shuck } \\
(\mathrm{kg} / \text { tree })\end{array}$ & \\
\hline 112 & $<2.25$ & $51 \mathrm{a}$ & $24 \mathrm{a}$ & $0.51 \mathrm{~b}$ \\
\hline 112 & $<2.50$ & $51 \mathrm{a}$ & $27 \mathrm{a}$ & $0.54 \mathrm{~b}$ \\
\hline 112 & $<2.75$ & $83 \mathrm{~b}$ & $19 \mathrm{a}$ & $0.23 \mathrm{a}$ \\
\hline 112 & $<3.00$ & $62 \mathrm{a}$ & $22 \mathrm{a}$ & $0.36 \mathrm{a}$ \\
\hline $224^{y}$ & --- & $79 \mathrm{~b}$ & $20 \mathrm{a}$ & $0.27 \mathrm{a}$ \\
\hline
\end{tabular}

${ }^{2}$ Mean separation by Proc. GLM, PDIFF ( $t$ test) option at $P \leq 0.05$. 